\title{
Application of Waste Engine Oil for Improving Ilmenite Flotation Combined with Sodium Oleate Collector
}

\author{
Qingyao Yu, Fuqiang Tian, Yijun Cao, Guixia Fan *, Haiqing Hao, Weijun Peng, Guoli Zhou and Peng Li * \\ School of Chemical Engineering, Zhengzhou University, Zhengzhou 450001, China; yuqingyaoya@126.com (Q.Y.); \\ 17854335916@163.com (F.T.); yijuncao@126.com (Y.C.); yesterday1019@163.com (H.H.); pwj@zzu.edu.cn (W.P.); \\ zhouguoli666666@163.com (G.Z.) \\ * Correspondence: zdhgfgx@zzu.edu.cn (G.F.); zdhglipeng@zzu.edu.cn (P.L.)
}

Citation: Yu, Q.; Tian, F.; Cao, Y.; Fan, G.; Hao, H.; Peng, W.; Zhou, G.; Li, P. Application of Waste Engine Oil for Improving Ilmenite Flotation Combined with Sodium Oleate Collector. Minerals 2021, 11, 1242. https://doi.org/10.3390/min11111242

Academic Editor: Saeed Chehreh Chelgani

Received: 30 September 2021 Accepted: 4 November 2021 Published: 9 November 2021

Publisher's Note: MDPI stays neutral with regard to jurisdictional claims in published maps and institutional affiliations.

Copyright: (c) 2021 by the authors. Licensee MDPI, Basel, Switzerland. This article is an open access article distributed under the terms and conditions of the Creative Commons Attribution (CC BY) license (https:// creativecommons.org/licenses/by/ $4.0 /$ )

\begin{abstract}
Collectors commonly have synergetic effects in ores flotation. In this work, a waste engine oil (WEO) was introduced as a collector to an ilmenite flotation system with sodium oleate (NaOL). The results show that the floatability of ilmenite was significantly improved by using WEO and $\mathrm{NaOL}$ as a combined collector. The recovery of ilmenite was enhanced from $71.26 \%$ (only NaOL) to $93.89 \%$ (WEO/NaOL combined collector) at the $\mathrm{pH}$ of 6.72 . The optimum molar ratio of $\mathrm{NaOL}$ to WEO was about 2.08 to 1 . The WEO and NaOL also have synergetic effects for the collection of ilmenite, because to obtain the ilmenite recovery of $53.96 \%$, the dosage of $45 \mathrm{mg} / \mathrm{L} \mathrm{NaOL}$ is equal to $38.56 \mathrm{mg} / \mathrm{L} \mathrm{WEO} / \mathrm{NaOL}$ combined collector (30 mg/L NaOL + $8.56 \mathrm{mg} / \mathrm{L} \mathrm{WEO}$ ). In other words, $15 \mathrm{mg} / \mathrm{L}$ of $\mathrm{NaOL}$ can be replaced by $8.56 \mathrm{mg} / \mathrm{L}$ of WEO. It is an effective way to reduce the dosage of the collector and reuse WEO. Therefore, it is a highly valuable and environmentally friendly approach for WEO reuse. WEO mainly consists of oxygen functional groups, aromatics, and long-chain hydrocarbons, especially for the $\mathrm{RCONH}_{2}$ and $\mathrm{RCOOH}$, thereby forming a strong interaction on the ilmenite surface. The adsorption mechanism of waste engine oil and sodium oleate on the ilmenite surface is mainly contributed by chemical adsorption. Therefore, WEO exhibits superior synergistic power with $\mathrm{NaOL}$ as a combined collector. Herein, this work provided an effective collector for ilmenite flotation and a feasible approach for reducing NaOL dosage and recycling $\mathrm{WEO}$.
\end{abstract}

Keywords: ilmenite; flotation; waste engine oil; combined collector; adsorption mechanism

\section{Introduction}

Titanium, a significant strategic metal, has been extensively used in aerospace, shipbuilding, medical devices, and other fields [1,2]. Ilmenite is rich in titanium resources; thereby, it is considered as the major mineral resource of titanium in China [3]. However, the separation of ilmenite faces many challenges due to the complex composition and low grade for ilmenite. The conventional separation of titanium includes gravity separation, magnetic separation, and electric separation. However, these techniques were only suitable for the $+74 \mu \mathrm{m}$ fraction. It is difficult to achieve effective separation of ilmenite for the $-74 \mu \mathrm{m}$ fraction by conventional methods [4]. Flotation is an effective separation technique to retrieve fine mineral particles, and it is widely used in the mineral industry [5-7]. The versatility of this process depends on the proper use of reagents, which are added into the pulp to induce wettability differences between ilmenite and other minerals in the ore. The sodium oleate (NaOL), as a typical and commercial collector for ilmenite flotation [6,8], has the characteristics of strong collecting ability but large dosage. The main optimization approach for ilmenite flotation is NaOL modification or combination with other reagents [9-15]. However, the route of NaOL modification is long and costly. The mixture of NaOL and D-phenylalanine performed positive synergistic adsorption in diaspore [10]. Xu et al. claimed that dodecyl amine-hydrochloride/NaOL has better hydrophobicity and collection performance than a single agent in muscovite flotation [11]. 
Herein, the combination of $\mathrm{NaOL}$ with other reagents is more appropriate for improving the collecting ability and reducing the reagents' cost. Even though, those collectors are still expensive.

Waste engine oil (WEO) is contaminated by impurities, oxidized, or decomposed matters, when using various vehicles, ships, and other machinery [16]. Approximately 40 million metric tons is produced every year; about $60 \%$ of the products become WEO all over the world [17]. It will bring a series of hazards if the WEO is not handled properly $[18,19]$. To reduce its harmful effects, the WEO should be recycled and reused. However, traditional approaches need to use corrosive and toxic substances, or strict conditions, such as vacuum distillation [20]. It will not only cause serious environmental pollution, it will also endanger human survival environment and health as well as waste valuable resources again. Therefore, how to effectively reuse WEO has become an important global imperative problem. The WEO has multiple substances such as hydrocarbons, esters, heteroatom compounds, and so on [21]. The WEO has potential application in flotation. The effect of WEO as a collector on the coal gasification waste flotation separation was investigated. The coal gasification waste was divided to cleaner concentrate carbons for fuel use and qualified tailings for building materials with a WEO collector. The goals of "Carbons Recycle" and "Waste Disposal by Waste" were realized [22].

In this work, a WEO was firstly introduced to enhance the collecting property of ilmenite with $\mathrm{NaOL}$ as a collector. The chemical compositions and structural features of the WEO were investigated by gas chromatography/mass spectrometry (GC/MS) and Fourier transform infrared spectroscopy (FTIR). The synergistic adsorption mechanism of $\mathrm{WEO} / \mathrm{NaOL}$ combined collector on the ilmenite surface was analyzed by zeta potential, FTIR, and X-ray photoelectron spectroscopy (XPS). This work provided an economical and effective collector for ilmenite flotation. Meanwhile, it is a suitable way to recycle WEO, reduce $\mathrm{NaOL}$ dosage, and improve the ilmenite recovery.

\section{Material and Methods}

\subsection{Characteristics of the Material}

The ilmenite sample was obtained from Panzhihua, Sichuan Province, China. The ilmenite sample was ground by a ball mill. The micro-flotation was carried out with $-74+38 \mu \mathrm{m}$ particle size samples. Table 1 and Figure 1 illustrated the chemical constituents and mineral components of ilmenite by $\mathrm{X}$-ray fluorescence spectrometer (XRF, Holland) and X-ray diffraction (XRD, Holland), respectively. As shown in Figure 1, the ilmenite was of high purity. As shown in Table 1, the Ti and Fe are the main elements of ilmenite. The purity of ilmenite is $93.38 \%$ (by calculation), as the $\mathrm{TiO}_{2}$ grade of the ilmenite sample is $49.12 \%$, and the theoretical grade of $\mathrm{TiO}_{2}$ in ilmenite is $52.63 \%$.

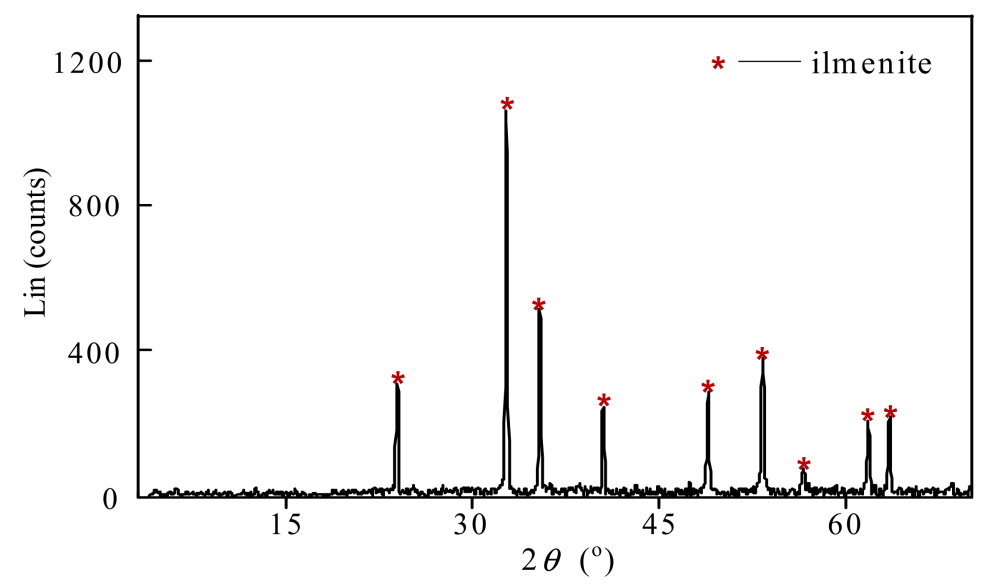

Figure 1. The XRD patterns of the ilmenite sample. 
Table 1. The chemical composition of the ilmenite sample.

\begin{tabular}{ccccccccc}
\hline Element. & $\mathrm{FeO}$ & $\mathrm{TiO}_{2}$ & $\mathrm{SiO}_{2}$ & $\mathrm{Al}_{2} \mathbf{O}_{3}$ & $\mathrm{MgO}$ & $\mathrm{CaO}$ & $\mathrm{MnO}$ & Others \\
\hline Content $(\%)$ & 37.67 & 49.12 & 3.15 & 2.83 & 4.14 & 0.75 & 0.60 & 1.74 \\
\hline
\end{tabular}

The WEO was collected from a repair shop in Zhengzhou, Henan Province, China. Chemical reagents were analytically pure. The NaOL collector was purchased from Aladdin Industrial Corporation, China. The $\mathrm{pH}$ of the pulp was adjusted using $\mathrm{HCl}$ and $\mathrm{NaOH}$ solution. The resistivity of ultrapure water was more than $18.2 \mathrm{M} \Omega / \mathrm{cm}$.

\subsection{Flotation Tests}

Flotation tests have been reported in the literature [23,24]. First, $2.0 \mathrm{~g}$ of ilmenite and $40 \mathrm{~mL}$ of deionized water were added into the XFG flotation cell with an agitating rate of $1600 \mathrm{r} / \mathrm{min}$. The $\mathrm{pH}$ of the pulp was adjusted by $\mathrm{NaOH}$ or $\mathrm{HCl}$ solution. The pulp was stirred for $2 \mathrm{~min}$. Subsequently, the WEO was added into the flotation cell and stirred for $1 \mathrm{~min}$; then, $\mathrm{NaOL}$ was added into the flotation cell and stirred for $2 \mathrm{~min}$. For contrast, a parallel test was carried out that consisted of only adding $\mathrm{NaOL}$ into the flotation cell and stirring for $3 \mathrm{~min}$. The flotation was maintained for $3 \mathrm{~min}$. Finally, the concentrate and tailings were dried and weighed to calculate the flotation recovery.

\subsection{Adsorption Mechanism Tests}

The zeta potentials of samples were measured by a Zetasizer Nano ZS90 analyzer (Malvern, Worcestershire, Britain). The suspension was prepared by mixing $20 \mathrm{mg}$ of ilmenite and $40 \mathrm{~mL}$ of ultrapure water. The collector was introduced to the suspension and adjusted to several $\mathrm{pH}$ values; then, the mixture was transferred to the sample tube. The $\mathrm{KNO}_{3}$ solution $\left(1 \times 10^{-3} \mathrm{~mol} / \mathrm{L}\right)$ was used as background electrolyte [25]. The conductivity and $\mathrm{pH}$ of the suspension were continuously monitored during the whole measurement. Each of the samples was measured at least five times, and the final results were averaged.

The FTIR spectra of ilmenite and reagents were recorded by an FTIR spectrometer (Nicolet iS10, Thermo Electron, NJ, USA). First, $2.0 \mathrm{~g}$ of ilmenite was introduced into $40 \mathrm{~mL}$ of solution at the corresponding $\mathrm{pH}$ and stirred for $5 \mathrm{~min}$; then, it was mixed with $\mathrm{NaOL}$ or/and WEO for $10 \mathrm{~min}$. After static stratification, they were washed and filtered with deionized water three times. Subsequently, the ilmenite sample and absorbed reagents were dried in a vacuum desiccator. Meanwhile, the dried ilmenite, WEO, and NaOL were analyzed by FTIR. Then, a $1 \mathrm{mg}$ mineral sample and $100 \mathrm{mg}$ of spectroscopic grade $\mathrm{KBr}$ were mixed and pressed to tablets for FTIR measurements.

The XPS (Thermo 250XI, Waltham, MA, USA) was used to determine the spectrum of ilmenite powder adsorbed in the reagents. The specimen preparation for XPS was consistent with the sampling method of FTIR.

The organic compounds in WEO were analyzed by GC/MS (GC-2014C, Japan) The method was used to identify the chemical composition of WEO [16]. The furnace program performed from 70 to $300{ }^{\circ} \mathrm{C}$ at a rate of $10{ }^{\circ} \mathrm{C} / \mathrm{min}$, and then, the temperature was maintained at $300{ }^{\circ} \mathrm{C}$ for $10 \mathrm{~min}$. The peak area normalization method was applied to calculate the corresponding content of component in WEO.

\section{Results and Discussion}

\subsection{Effects of WEO on Ilmenite Flotation}

As exhibited in Figure 2a, the concentrate recovery of ilmenite flotation was significantly improved by adding WEO, with the WEO dosage of $30 \mathrm{mg} / \mathrm{L}$ and the NaOL dosage of $60 \mathrm{mg} / \mathrm{L}$. With the $\mathrm{pH}$ increasing, the ilmenite recovery climbs up and then declines, and the recovery increment ranges from $15.05 \%(\mathrm{pH}=2.38)$ to $25.30 \%(\mathrm{pH}=4.96)$. The optimized ilmenite flotation recovery reached $93.89 \%$ from $71.26 \%$ with adding WEO at the $\mathrm{pH}$ of 6.72 . Therefore, WEO can significantly improve the concentrate recovery of ilmenite flotation with the presence of the $\mathrm{NaOL}$. Compared to the $\mathrm{pH}$ of 6.72 , the recovery declines as the $\mathrm{pH}$ increases $(\mathrm{pH}=9.02$ and $\mathrm{pH}=11.72)$, with the NaOL dosage of $60 \mathrm{mg} / \mathrm{L}$. 
However, the recovery increment is still over $16 \%$ with adding $30 \mathrm{mg} / \mathrm{L}$ of WEO. Therefore, the WEO is a suitable collector for improving the flotation behavior of ilmenite with the presence of the NaOL.
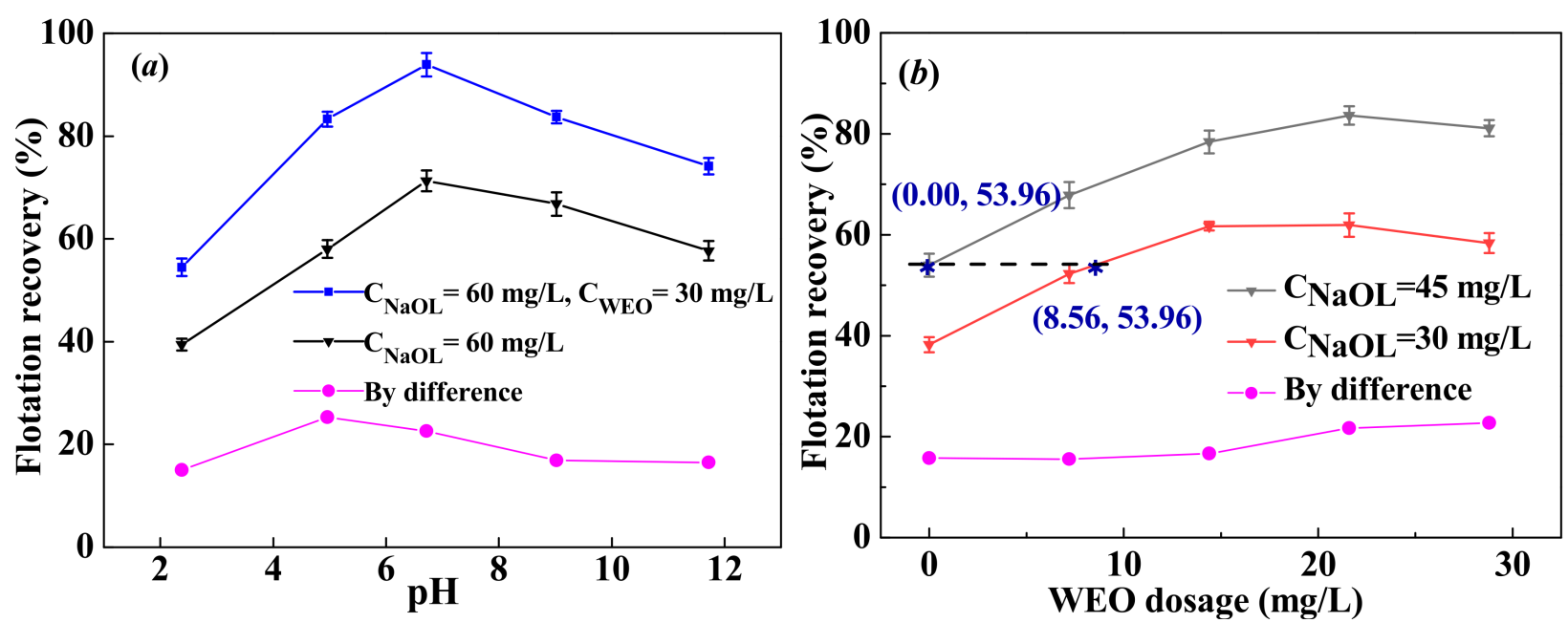

Figure 2. The flotation recovery of ilmenite at different $\mathrm{pH}$ (a) and collector dosage (b).

This does not mean that a WEO dosage would always promote the recovery. The dosage of WEO and NaOL has an optimal value, which is most conducive to the production of ilmenite. The ratio of the combined collector is an important index for ilmenite flotation [26]. As shown in Figure 2b, as the dosage of WEO increased, the ilmenite recovery climbed up and then declined. The ilmenite recovery reached the top point when the combined collector was prepared by $45 \mathrm{mg} / \mathrm{L} \mathrm{NaOL}$ and $21.60 \mathrm{mg} / \mathrm{L} W E O$, or $30 \mathrm{mg} / \mathrm{L}$ $\mathrm{NaOL}$ and $14.40 \mathrm{mg} / \mathrm{L} \mathrm{WEO}$. Therefore, the optimum molar ratio of $\mathrm{NaOL}$ to WEO was about 2.08 to 1 .

Both of the results presented in Figure 2a,b proved that the WEO/NaOL combined collector has a stronger collecting capacity for ilmenite compared to a single $\mathrm{NaOL}$ collector. Moreover, as seen in Figure 2b, to obtain the ilmenite recovery of $53.96 \%$, the dosage of $45 \mathrm{mg} / \mathrm{L} \mathrm{NaOL}$ is equal to $38.56 \mathrm{mg} / \mathrm{L} \mathrm{WEO} / \mathrm{NaOL}$ combined collector ( $30 \mathrm{mg} / \mathrm{L} \mathrm{NaOL}+8.56 \mathrm{mg} / \mathrm{L} \mathrm{WEO})$, indicating that the WEO and the $\mathrm{NaOL}$ also have synergetic effects for the collection of ilmenite. On the other hand, when the dosage of $\mathrm{NaOL}$ is $45 \mathrm{mg} / \mathrm{L}$ or the dosage of WEO is $38.56 \mathrm{mg} / \mathrm{L}$, the flotation recovery of ilmenite can achieve $53.96 \%$. In other words, $15 \mathrm{mg} / \mathrm{L}$ of NaOL can be replaced by $8.56 \mathrm{mg} / \mathrm{L}$ of WEO. It is an effective way to reduce the dosage and cost of the collector by adding WEO. It is also an efficient approach for WEO reuse, because waste was converted to valuable flotation collectors. Therefore, it is a highly valuable and environmentally friendly approach for WEO reuse.

\subsection{Adsorption Mechanism Analysis}

\subsubsection{Zeta Potential Shifts}

The zeta potentials of ilmenite treated by $\mathrm{NaOL}$ or/and WEO in different solutions are shown in Figure 3. The isoelectric point of pure ilmenite is close to $\mathrm{pH}=6.0[27,28]$. When $\mathrm{NaOL}$ was used as a single collector, the zeta potentials of ilmenite are negatively shifted, indicating the adsorption of $\mathrm{NaOL}$ on the ilmenite surface [8]. When both WEO and $\mathrm{NaOL}$ were used at $\mathrm{pH}<8.0$, the zeta potentials of the ilmenite surface are more negatively than that treated only by $\mathrm{NaOL}$. It indicates that the cooperation of $\mathrm{NaOL}$ and $\mathrm{WEO}$ can promote the flotation performance at $\mathrm{pH}<8.0$. However, the WEO is not suitable for ilmenite flotation at $\mathrm{pH}>8.0$. The results showed that the combined collector and the ilmenite have stronger adsorption at $\mathrm{pH}<8.0$ [29]. 


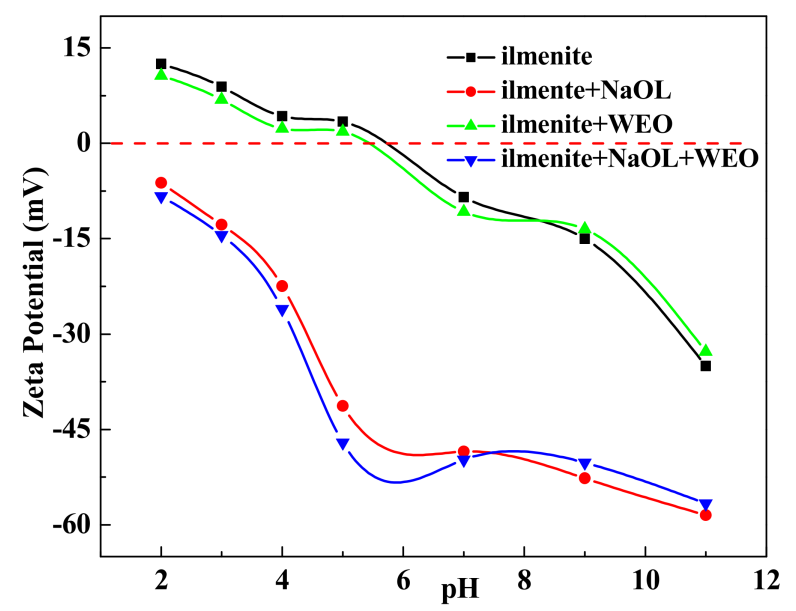

Figure 3. Effect of $\mathrm{pH}$ on zeta potentials of ilmenite treated by NaOL or/and the WEO.

\subsubsection{Infrared Absorption Shifts}

The FTIR spectra of WEO, NaOL, ilmenite, and ilmenite treated with WEO or/and $\mathrm{NaOL}$ are presented in Figure 4. As shown in Figure 4a, the FTIR spectrum of ilmenite was basically consistent with the chemical bond vibration mode reported previously [30]. In the FTIR spectrum of $\mathrm{NaOL}$, the bands at 2923 and $2853 \mathrm{~cm}^{-1}$ belong to the $\mathrm{C}-\mathrm{H}$ stretching vibration $\left(-\mathrm{CH}_{2}-\right.$ and $\left.-\mathrm{CH}_{3}\right)$, while the band at $721 \mathrm{~cm}^{-1}$ was attributed to $-\left(\mathrm{CH}_{2}\right)$ n- deformation. The peaks at 1561,1464, and $1427 \mathrm{~cm}^{-1}$ were caused by -COO- vibration [14,15]. In the FTIR spectrum of WEO, the bands at 2920, 2852, 1462, and $1377 \mathrm{~cm}^{-1}$ were attributed to the $\mathrm{C}-\mathrm{H}$ vibration of methyl/methylene, while the peak at $722 \mathrm{~cm}^{-1}$ was attributed to $\mathrm{C}-\mathrm{H}$ bending vibration of the substituted aromatics and aromatic hydrocarbon $[31,32]$. It indicates that non-polar alkanes/olefins exist in WEO, which can increase its fixation degree on the ilmenite surface and improve the floatability of the ilmenite surface. The peak at $1700 \mathrm{~cm}^{-1}$ belongs to the $\mathrm{C}=\mathrm{O}$ stretching vibration of carboxyl and carbonyl [33], while the bands at 1605 and $1156 \mathrm{~cm}^{-1}$ originated from the $\mathrm{C}-\mathrm{N}$ stretching vibration and $\mathrm{C}=\mathrm{N}$ stretching vibration of amide component, respectively [34]. The polar component is beneficial to the adsorption of active sites on the ilmenite surface. Therefore, the synergistic effect of the polar and non-polar components in WEO is conducive to the ilmenite flotation.

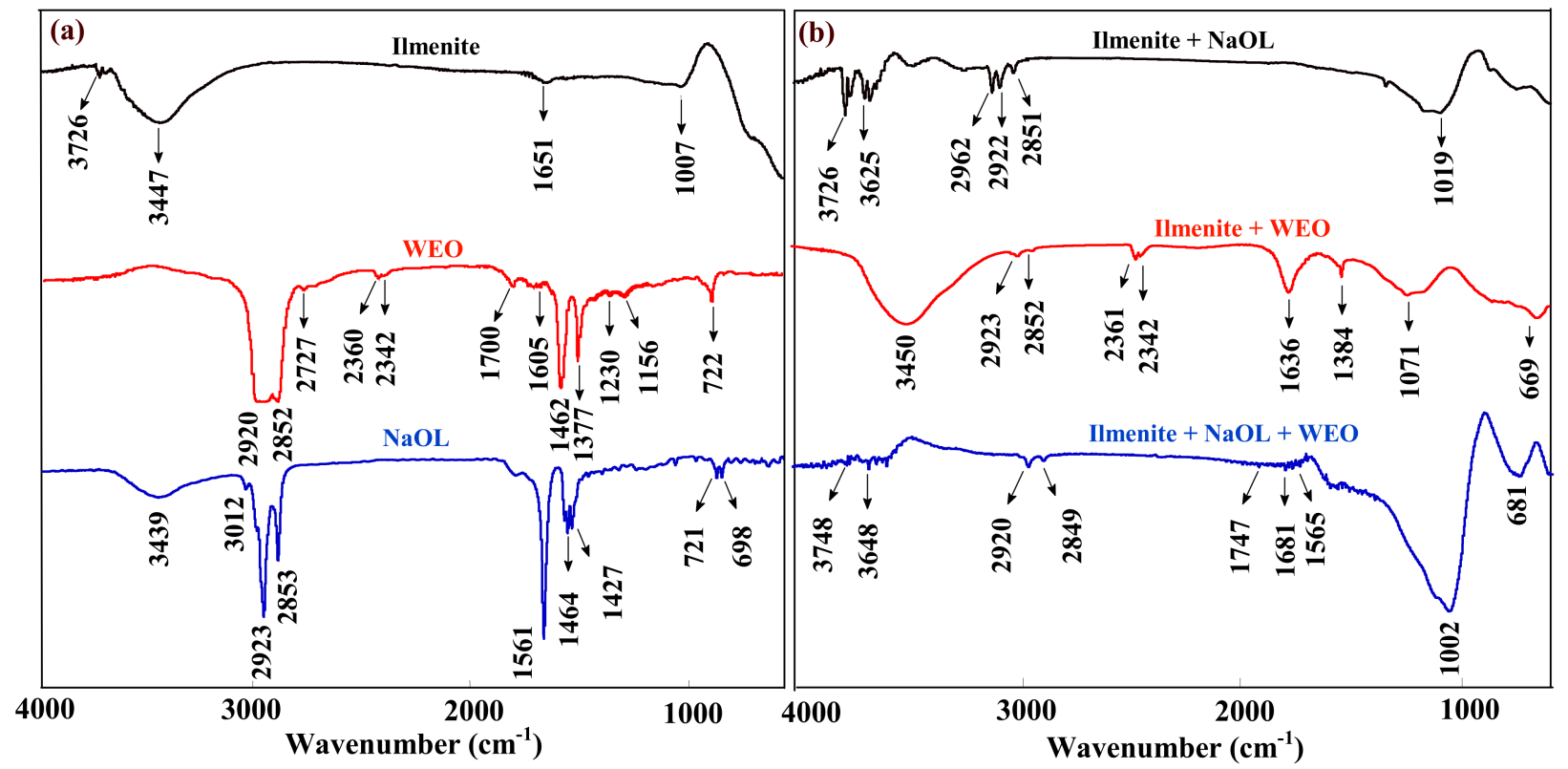

Figure 4. FTIR spectra of (a) ilmenite, WEO, and NaOL, and (b) ilmenite treated with WEO or/and NaOL. 
Figure $4 \mathrm{~b}$ performed the FTIR spectra of ilmenite treated with NaOL or/and WEO. Comparing the FTIR spectrum of ilmenite with ilmenite treated by NaOL, new bands at 2962, 2922, and $2851 \mathrm{~cm}^{-1}$ were found on the spectrum of the ilmenite surface treated with NaOL. The band at $2962 \mathrm{~cm}^{-1}$ moved to a lower wavenumber by $50 \mathrm{~cm}^{-1}$ compared to that in the FTIR spectrum of NaOL. It can be inferred that NaOL is adsorbed on the ilmenite surface [35]. Compared with the FTIR spectrum of ilmenite, characteristic peaks of WEO (at approximately 2923, 2852, 2361, 2342, 1384, and $669 \mathrm{~cm}^{-1}$ ) were observed on the spectrum of ilmenite treated by WEO. The new band at $1636 \mathrm{~cm}^{-1}$ was shifted by $31 \mathrm{~cm}^{-1}$ on ilmenite treated by WEO. This proves that WEO can react on the ilmenite surface. Comparing the FTIR spectrum with WEO, the new bands at 1747 and $1681 \mathrm{~cm}^{-1}$ were shifted by 47 and $76 \mathrm{~cm}^{-1}$ on the spectrum of ilmenite treated by NaOL and WEO. Other peaks at 2920, 2849, and $681 \mathrm{~cm}^{-1}$ may be the superposition of $\mathrm{NaOL}$ and WEO. These results indicated the combined collector adsorbed on the ilmenite surface via the form of chemical adsorption.

\subsubsection{Concurrent Forms of Elements}

The synergistic collection mechanism of $\mathrm{NaOL}$ or/and WEO on the ilmenite surface was investigated by XPS. Table 2 listed the chemical shift of the binding energy on the ilmenite surface treated by NaOL or/and WEO. As listed in Table 2, after ilmenite was treated by the combined collector, the chemical shift of Ti was not obvious, while the chemical shift of Fe on the ilmenite surface changed by $0.72 \mathrm{eV}$. This result indicated that the combined collector could react with the active site of Fe on the ilmenite surface because the chemical environment for Fe was transformed [35].

Table 2. Binding energies of elements on the ilmenite surface treated with WEO or/and NaOL (eV).

\begin{tabular}{|c|c|c|c|c|c|c|c|c|c|c|c|c|}
\hline \multirow{2}{*}{ Sample } & \multicolumn{6}{|c|}{ Binding Energy $(\mathrm{eV})$} & \multicolumn{6}{|c|}{ Chemical Shift (eV) } \\
\hline & Fe 2p3/2 & Fe 2p1/2 & O 1s & O 1s & Ti 2p3/2 & Ti 2p1/2 & $\mathrm{Fe} 2 \mathrm{p} 3 / 2$ & Fe $2 p 1 / 2$ & O 1s & O 1s & Ti 2p3/2 & Ti 2p1/2 \\
\hline Ilmenite & 710.31 & 723.32 & 531.42 & 529.55 & 457.87 & 463.54 & - & - & - & - & - & - \\
\hline Ilmenite + NaOL & 710.38 & 724.2 & 531.47 & 529.5 & 457.71 & 463.52 & 0.07 & 0.88 & 0.05 & -0.05 & -0.16 & 0.02 \\
\hline Ilmenite + WEO & 710.32 & 723.14 & 531.47 & 529.58 & 457.83 & 463.57 & 0.01 & -0.18 & 0.05 & 0.03 & 0.04 & 0.03 \\
\hline $\begin{array}{c}\text { Ilmenite + NaOL + } \\
\text { WEO }\end{array}$ & 710.16 & 724.04 & 531.43 & 529.51 & 457.86 & 463.57 & -0.15 & 0.72 & -0.01 & -0.04 & -0.01 & 0.03 \\
\hline
\end{tabular}

The Fe 2p level split into two peaks of Fe 2p3/2 and Fe 2p1/2 because of the spin-orbit coupling [36]. Figure 5a illustrated the high-resolution spectrum of Fe $2 p$ and its separation fitting peaks. Among these peaks, the separated peaks for the ilmenite samples treated by collectors were attributed to $\mathrm{Fe}^{3+}$ and $\mathrm{Fe}^{2+}$ species, respectively [37]. Compared with original ilmenite, the binding energy of Fe $2 p$ changed from 710.31 to $710.16 \mathrm{eV}$ and from 723.32 to $724.04 \mathrm{eV}$ separately when ilmenite was treated by the combined collector. This shows that the combined collector contributed possibly its electron to iron species for the change of chemical environment to Fe ions on the ilmenite surface [38,39]. The $\mathrm{O} 1 \mathrm{~s}$ spectra of ilmenite treated with $\mathrm{NaOL}$ or/with $\mathrm{WEO}$ are presented in Figure $5 \mathrm{~b}$. The $\mathrm{O} 1 \mathrm{~s}$ spectrum of ilmenite was fitted to two components, namely the Ti-O bond (529.55 eV) and Fe-O bond $(531.42 \mathrm{eV})$ [23]. Figure $5 \mathrm{c}$ was the high resolution of the Ti $2 \mathrm{p}$ spectra of ilmenite treated by $\mathrm{NaOL}$ and/or WEO. Comparing ilmenite treated by the combined collector with ilmenite, the binding energy of Ti 2p3/2 and Ti 2p1/2 centered from 457.87 to $457.86 \mathrm{eV}$ and from 463.54 to $463.57 \mathrm{eV}$, respectively [40]. Since the binding energy was comparatively slight, it indicated that the Ti atom may be not the reaction site on the ilmenite surface after ilmenite was treated by the combined collector. Based on the related report, in weak acid or weak alkaline solutions, titanium ions mainly existed on $\mathrm{Ti}(\mathrm{OH})_{4}$ in a stable form, while ferrous ions could be active sites in the form of $\mathrm{Fe}^{2+}$ and $\mathrm{FeOH}^{+}$for collector absorption [41,42]. The XPS result was consistent with the FTIR result. According to the results of XPS analyses, Fe ions on the ilmenite surface acted as the active sites to react with the combined collector, indicating there was chemical adsorption between the combined collector and ilmenite. 

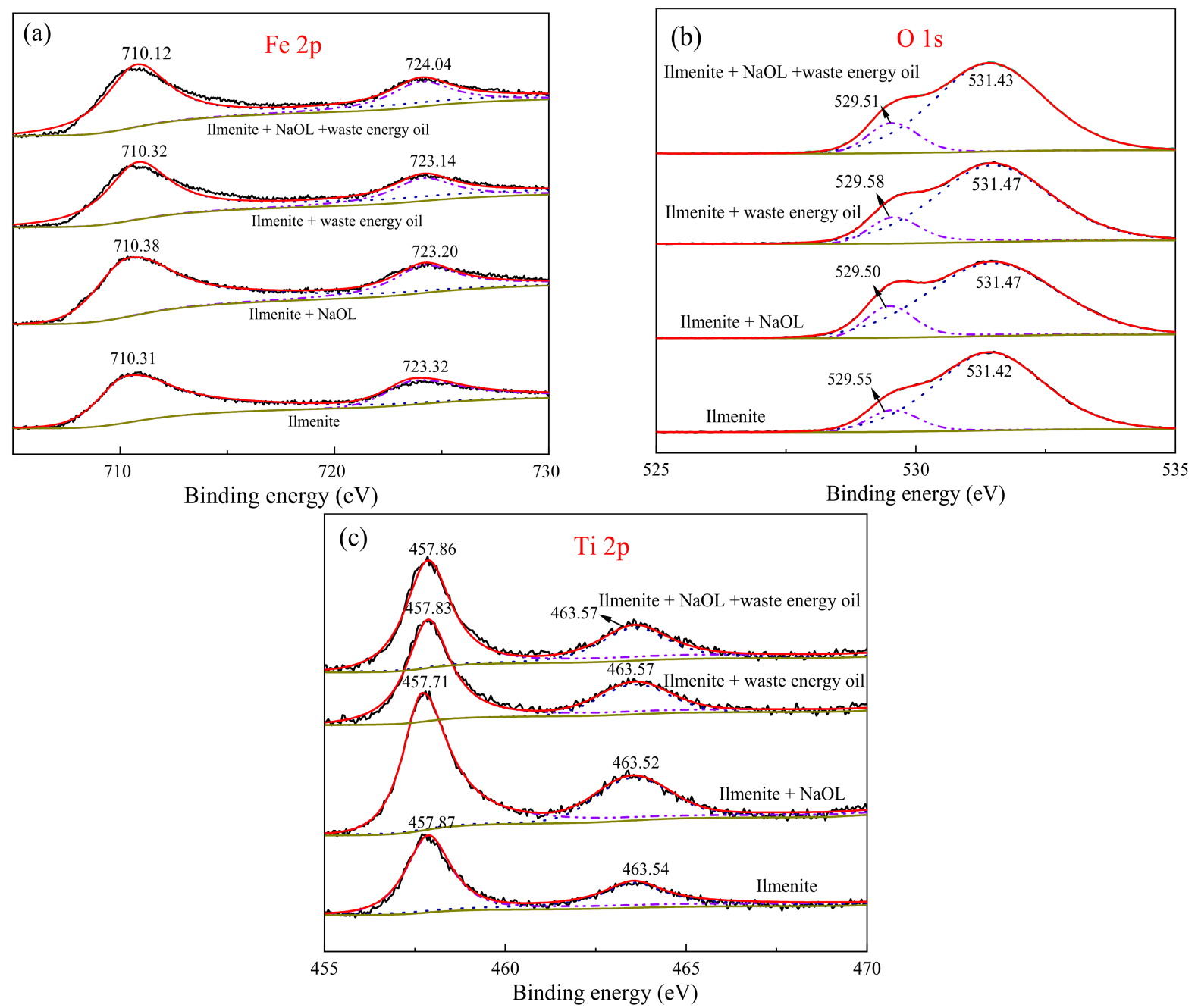

Figure 5. The high resolution of Fe $2 \mathrm{p}(\mathbf{a}), \mathrm{O} 1 \mathrm{~s}(\mathbf{b})$, and Ti $2 \mathrm{p}(\mathbf{c})$ spectra on the ilmenite surface treated with WEO or/and NaOL.

\subsection{Interactive Mechanism of WEO/NaOL on Ilmenite Surface}

The interactive mechanism between the combined collector and ilmenite were related with the aqueous species of $\mathrm{WEO}, \mathrm{NaOL}$, and the crystal structure of ilmenite [43]. Figure 6 illustrates the chromatogram of WEO, and Table 3 lists the relative content of identified chemicals. As shown in Figure 6, the chromatogram was attributed to the benzene derivatives at low retention time, oxygenated compounds at medium retention time, and long-chain hydrocarbons at high retention time. As illustrated in Table 3, WEO was mainly composed of chemicals with the carbon number of 19 to 38, especially the carbon atom ranges from 24 to 28 [22], which accounted for half of the total. These compounds in WEO determined the adsorption characteristics on the ilmenite surface. The results showed that benzene derivatives and oxygenated compounds in WEO can largely bond with the active sites of ilmenite, and its long-chain hydrocarbons can enhance the hydrophobic property on the ilmenite surface. 


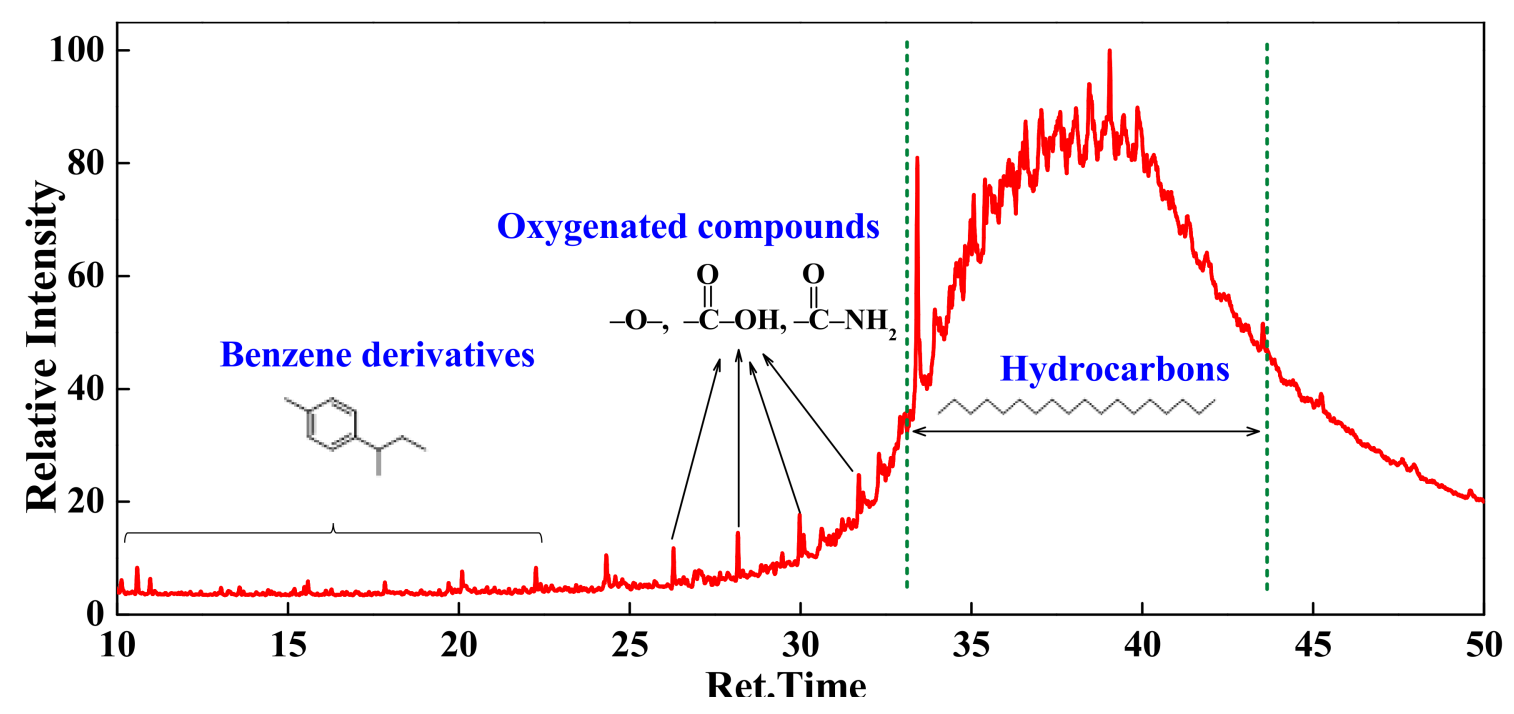

Figure 6. The GC/MS chromatogram of WEO.

Table 3. The chemical composition of C19 to C38 of WEO.

\begin{tabular}{cccc}
\hline Carbon Number & Relative Content (\%) & Carbon Number & Relative Content (\%) \\
\hline C19 & 0.51 & C28 & 7.16 \\
C20 & 3.10 & C29 & 3.33 \\
C21 & 1.98 & C30 & 0.97 \\
C22 & 4.79 & C32 & 1.64 \\
C23 & 2.16 & C33 & 1.96 \\
C24 & 11.63 & C34 & 4.23 \\
C25 & 11.47 & C35 & 7.58 \\
C26 & 9.57 & C37 & 0.93 \\
C27 & 10.04 & C38 & 0.96 \\
\hline
\end{tabular}

Under weak acid or alkali conditions $(\mathrm{pH}=6.0-9.0), \mathrm{WEO}$ and $\mathrm{NaOL}$ existed mainly in these three forms: (1) amphoteric species with negatively charged (-COO-, $-\mathrm{CO}-\mathrm{NH}-$, $-\mathrm{O}-)$ and positively charged $\left(-\mathrm{NH}_{2}\right)$ groups; (2) saturated alkanes with different carbon length; (3) species with unsaturated double or triple bonds. As stated in XPS analysis, the active site on the ilmenite surface was principally iron in weak acid or weak alkaline solution. Therefore, as shown in Figure 7, WEO and NaOL in the solution could act on the ilmenite surface in different forms and react with iron active sites to form related molecules. It could be speculated that the-COO- groups for WEO and NaOL could contribute the frontier electrons of $\mathrm{O}$ atoms to $\mathrm{Fe}$ atoms on the ilmenite surface. The reactions could involve the chelation adsorption as $-\mathrm{CO}-\mathrm{NH}-,-\mathrm{O}-$, and other related components between combined collector and ilmenite. NaOL could be adsorbed in the ilmenite surface by forming hydrogen bonds between $-\mathrm{C}=\mathrm{O}$ and $-\mathrm{NH}_{2}$ groups in WEO. It was concluded that the adsorption mechanism between combined collector and ilmenite primarily included chemical adsorption, electrostatic interaction, and hydrogen bond adsorption. The mixture of $\mathrm{NaOL}$ and WEO increased the adsorption capacity of the ilmenite surface. 


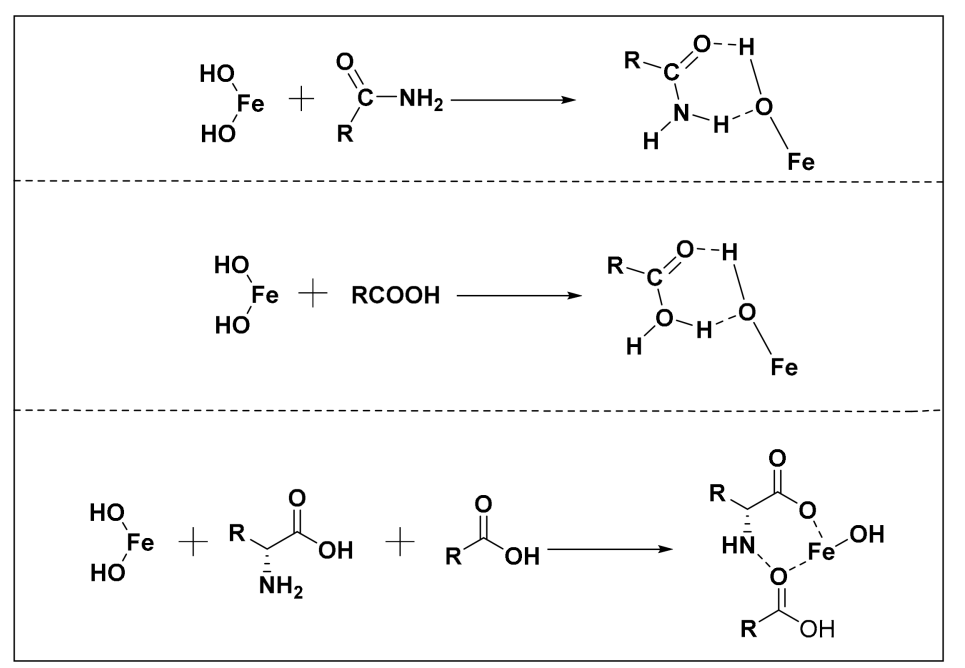

Figure 7. The association equations of combined collector (NaOL and WEO) on the ilmenite surface.

\section{Conclusions}

A new $\mathrm{WEO} / \mathrm{NaOL}$ combined collector was prepared and efficiently used for ilmenite flotation. The NaOL dosage was significantly reduced when the WEO was used for ilmenite flotation to replace some of the NaOL. The optimum molar ratio of $\mathrm{NaOL}$ to WEO was about 2.08 to 1 . The $\mathrm{WEO}$ and $\mathrm{NaOL}$ also have synergetic effects on the ilmenite flotation, as the recovery of adding $8.56 \mathrm{mg} / \mathrm{L} \mathrm{WEO}$ is equal to $15 \mathrm{mg} / \mathrm{L} \mathrm{NaOL}$, while the initial $\mathrm{NaOL}$ dosage was $30 \mathrm{mg} / \mathrm{L}$. The combination of $\mathrm{NaOL}$ and WEO could increase their adsorption capacity on the ilmenite surface and improve the collection performance. The application of the $\mathrm{WEO} / \mathrm{NaOL}$ combined collector on ilmenite flotation can achieve the goal of "reusing WEO" and "reducing NaOL dosage" in ilmenite flotation, which also has potential application in the future industry.

Author Contributions: Formal analysis Q.Y., F.T., G.F., W.P., G.Z. and P.L.; investigation F.T., G.F. and H.H.; methodology Y.C., H.H., W.P., G.Z. and P.L.; Writing-original draft, Q.Y.; Writing-review \& editing, G.F. and P.L. All authors have read and agreed to the published version of the manuscript.

Funding: This research was funded by the National Natural Science Foundation of China (Grant No. U1908226, U1704252, 51704263), the IRTSTHN (No. 19IRTSTHN028), the Key scientific research program plan of colleges and universities in Henan Province (No. 21B530007), and the Key Specialized Research and Development Breakthrough Program in Henan province (212102310378).

Conflicts of Interest: The authors declare no conflict of interest.

\section{References}

1. Lammermann, N.; Schmid-Michels, F.; Weissmann, A.; Wobbe, L.; Hutten, A.; Kruse, O. Extremely robust photocurrent generation of titanium dioxide photoanodes bio-sensitized with recombinant microalgal light-harvesting proteins. Sci. Rep. $2019,9,2109$. [CrossRef] [PubMed]

2. Tschernitschek, H.; Borchers, L.; Geurtsen, W. Nonalloyed titanium as a bioinert metal—A review. Quintessence Int. 2006, 96, 12. [CrossRef]

3. Xu, L.; Tian, J.; Wu, H.; Lu, Z.; Yang, Y.; Sun, W.; Hu, Y. Effect of $\mathrm{Pb}^{2+}$ ions on ilmenite flotation and adsorption of benzohydroxamic acid as a collector. Appl. Surf. Sci. 2017, 425, 796-802. [CrossRef]

4. Zhang, X.; Liu, D.; Fang, J.; Xu, J. Study on influence of residual magnetite in Panzhihua ilmenite flotation, Earth Planet. Sci. Lett. 2011, 2, 83-88.

5. Xu, L.; Hu, Y.; Dong, F.; Gao, Z.; Wu, H.; Wang, Z. Anisotropic adsorption of oleate on diaspore and kaolinite crystals: Implications for their flotation separation. Appl. Surf. Sci. 2014, 321, 331-338. [CrossRef]

6. Bulatovic, S.; Wyslouzil, D.M. Process development for treatment of complex perovskite, ilmenite and rutile ores. Miner. Eng. 1999, 12, 1407-1417. [CrossRef]

7. Xu, L.; Tian, J.; Wu, H.; Fang, S.; Lu, Z.; Ma, C.; Sun, W.; Hu, Y. Anisotropic surface chemistry properties and adsorption behavior of silicate mineral crystals. Adv. Colloid Interface Sci. 2018, 256, 340-351. [CrossRef] 
8. Du, Y.; Meng, Q.; Yuan, Z.; Ma, L.; Zhao, X.; Xu, Y. Study on the flotation behavior and mechanism of ilmenite and titanaugite with sodium oleate. Miner. Eng. 2020, 152, 106366. [CrossRef]

9. Zhai, J.; Lu, X.; Chen, P.; Guan, C.; Sun, W.; Chen, W. A new collector scheme for strengthening ilmenite floatability in acidic pulp. J. Mater. Res. Technol. 2019, 8, 5053-5056. [CrossRef]

10. Li, H.; Chai, W.; Cao, Y.; Wu, Y.; Yang, S. Synergistic collection mechanism of D-phenylalanine and sodium oleate in flotation of diaspore from kaolinite. Appl. Surf. Sci. 2021, 538, 147937. [CrossRef]

11. Xu, L.; Hu, Y.; Tian, J.; Wu, H.; Wang, L.; Yang, Y.; Wang, Z. Synergistic effect of mixed cationic/anionic collectors on flotation and adsorption of muscovite. Colloids Surf. A Physicochem. Eng. Asp. 2016, 492, 181-189. [CrossRef]

12. Man, X.; Ou, L.; Wang, C.; Jin, S.; Ma, X. Flotation separation of diaspore and kaolinite by using a mixed collector of sodium sleate-tert dodecyl mercaptan. Front. Chem. 2019, 7, 813. [CrossRef] [PubMed]

13. Xu, L.; Tian, J.; Wu, H.; Lu, Z.; Sun, W.; Hu, Y. The flotation and adsorption of mixed collectors on oxide and silicate minerals. Adv. Colloid Interface Sci. 2017, 250, 1-14. [CrossRef]

14. Tian, J.; Xu, L.; Deng, W.; Jiang, H.; Gao, Z.; Hu, Y. Adsorption mechanism of new mixed anionic/cationic collectors in a spodumene-feldspar flotation system. Chem. Eng. Sci. 2017, 164, 99-107. [CrossRef]

15. Xu, L.; Wu, H.; Dong, F.; Wang, L.; Wang, Z.; Xiao, J. Flotation and adsorption of mixed cationic/anionic collectors on muscovite mica. Miner. Eng. 2013, 41, 41-45. [CrossRef]

16. Patel, N.; Shadangi, K.P. Thermochemical conversion of waste engine oil (WEO) to gasoline-rich crude oil. J. Mater. Cycles Waste Manag. 2020, 22, 536-546. [CrossRef]

17. Fuentes, M.J.; Font, R.; Gómez-Rico, M.F.; Martín-Gullón, I. Pyrolysis and combustion of waste lubricant oil from diesel cars: Decomposition and pollutants. J. Anal. Appl. Pyrolysis. 2007, 79, 215-226. [CrossRef]

18. Arpa, O.; Yumrutas, R.; Demirbas, A. Production of diesel-like fuel from waste engine oil by pyrolitic distillation. Appl. Energy. 2010, 87, 122-127. [CrossRef]

19. Udonne, J.D. A comparative study of recycling of used lubrication oils using distillation, acid and activated charcoal with clay methods. J. Petrol. Gas Eng. 2001, 2, 12-19.

20. Abro, R.; Chen, X.; Harijan, K.; Dhakan, Z.A.; Ammar, M. A comparative study of recycling of used engine oil using extraction by composite solvent, single solvent, and acid treatment methods. ISRN Chem. Eng. 2013, 1-5. [CrossRef]

21. Abdullah, H.B.; Irmawati, R.; Ismail, I.; Yusof, N.A. Utilization of waste engine oil for carbon nanotube aerogel production using floating catalyst chemical vapor deposition. J. Clean. Prod. 2020, 261, 121188. [CrossRef]

22. Fan, G.X.; Zhang, M.Y.; Peng, W.J.; Zhou, G.L.; Deng, L.J.; Chang, L.P.; Cao, Y.J.; Li, P. Clean products from coal gasification waste by flotation using waste engine oil as collector: Synergetic cleaner disposal of wastes. J. Clean. Prod. 2021, 286, 124943. [CrossRef]

23. Chen, P.; Zhai, J.H.; Sun, W.; Hu, Y.H.; Yin, Z.G.; Lai, X.S. Adsorption mechanism of lead ions at ilmenite/water interface and its influence on ilmenite flotability. J. Ind. Eng. Chem. 2017, 53, 285-293. [CrossRef]

24. Zhao, W.J.; Liu, D.W.; Wen, S.M.; Feng, Q.C. Surface modification of hemimorphite with lead ions and its effect on flotation and oleate adsorption. Appl. Surf. Sci. 2019, 483, 849-858. [CrossRef]

25. Lyu, F.; Gao, J.; Sun, N.; Liu, R.; Sun, X.; Cao, X.; Wang, L.; Sun, W. Utilisation of propyl gallate as a novel selective collector for diaspore flotation. Miner. Eng. 2019, 131, 66-72. [CrossRef]

26. Vidyadhar, A.; Kumari, N.; Bhagat, R.P. Adsorption mechanism of mixed collector systems on hematite flotation. Miner. Eng. 2012, 26, 102-104. [CrossRef]

27. Tian, J.; Xu, L.; Yang, Y.; Liu, J.; Zeng, X.; Deng, W. Selective flotation separation of ilmenite from titanaugite using mixed anionic/cationic collectors. Int. J. Miner. Process. 2017, 166, 102-107. [CrossRef]

28. Chen, P.; Zhai, J.; Sun, W.; Hu, Y.; Yin, Z. The activation mechanism of lead ions in the flotation of ilmenite using sodium oleate as a collector. Min. Eng. 2017, 111, 100-107. [CrossRef]

29. Wu, Y.; Su, S.; Peng, W.; Zhang, Y.; Fan, G.; Han, G.; Cao, Y. Optimization of fine ilmenite flotation performed with collectors. Miner. Met. Mater. Ser. 2019, 30, 301-309.

30. Guan, C.; Yin, Z.; Zhai, J.; Hu, Y.; Chen, P.; Sun, W. Surface modification of ilmenite by a novel surfactant dodecyliminodimethylenediphosphoinc acid and its sequent influence on ilmenite floatability. Sep. Sci. Technol. 2019, 55, 358-368. [CrossRef]

31. Ramos-Escobedo, G.T.; Pecina-Treviño, E.T.; Bueno Tokunaga, A.; Concha-Guerrero, S.I.; Ramos-Lico, D. Bio-collector alternative for the recovery of organic matter in flotation processes. Fuel 2016, 176, 165-172. [CrossRef]

32. Li, M.; Xia, Y.; Zhang, Y.; Ding, S.; Rong, G.; Cao, Y.; Xing, Y.; Gui, X. Mechanism of shale oil as an effective collector for oxidized coal flotation: From bubble-particle attachment and detachment point of view. Fuel 2019, 255, 115885. [CrossRef]

33. Xing, Y.; Gui, X.; Cao, Y.; Wang, D.; Zhang, H. Clean low-rank-coal purification technique combining cyclonic-static microbubble flotation column with collector emulsification. J. Clean. Prod. 2016, 153, 657-672. [CrossRef]

34. Meng, Q.; Yuan, Z.; Yu, L.; Xu, Y.; Du, Y. Study on the activation mechanism of lead ions in the flotation of ilmenite using benzyl hydroxamic acid as collector. J. Ind. Eng. Chem. 2018, 62, 209-216. [CrossRef]

35. Jie, Z.; Weiqing, W.; Jing, L.; Yang, H.; Qiming, F. Fe(III) as an activator for the flotation of spodumene, albite, and quartz minerals. Miner. Eng. 2014, 61, 16-22. [CrossRef]

36. Turu, Y.; Peter, H. Analysis of XPS spectra of $\mathrm{Fe}^{2+}$ and $\mathrm{Fe}^{3+}$ ions in oxide materials. Appl. Surf. Sci. 2008, 254, $2441-2449$.

37. Grosvenor, A.P.; Kobe, B.A.; Biesinger, M.C.; McIntyre, N.S. Investigation of multiplet splitting of Fe 2p XPS spectra and bonding in iron compounds. Surf. Interface Anal. 2004, 36, 1564-1574. [CrossRef] 
38. Zheng, X.P.; Misra, M.; Smith, R.W.; Qiao, J.K. Fersmite flotation with diphosphonic acid and other collectors. Miner. Eng. 1996, 9 , 331-341. [CrossRef]

39. Conradie, J.; Erasmus, E. XPS Fe 2p peaks from iron tris ( $\beta$-diketonates): Electronic effect of the $\beta$-diketonato ligand. Polyhedron 2016, 119, 142-150. [CrossRef]

40. Li, F.; Zhong, H.; Zhao, G.; Wang, S.; Liu, G. Adsorption of $\alpha$-hydroxyoctyl phosphonic acid to ilmenite/water interface and its application in flotation. Colloids Surf. A Physicochem. Eng. Asp. 2016, 490, 67-73. [CrossRef]

41. Fan, X.; Rowson, N.A. The effect of $\mathrm{Pb}\left(\mathrm{NO}_{3}\right)_{2}$ on ilmenite flotation. Miner. Eng. 2000, 13, 205-215. [CrossRef]

42. Xu, H.; Zhong, H.; Tang, Q.; Wang, S.; Zhao, G.; Liu, G. A novel collector 2-ethyl-2-hexenoic hydroxamic acid: Flotation performance and adsorption mechanism to ilmenite. Appl. Surf. Sci. 2015, 353, 882-889. [CrossRef]

43. Fan, G.; Zhang, C.; Wang, T.; Deng, J.; Cao, Y.; Chang, L.; Zhou, G.; Wu, Y.; Li, P. New insight into surface adsorption thermodynamic, kinetic properties and adsorption mechanisms of sodium oleate on ilmenite and titanaugite. Adv. Powder Technol. 2020, 31, 3628-3639. [CrossRef] 